\title{
Effects of Different Seeding Rate and Row Spacing on Yield and Yield Components of Narbon Vetch (Vicia narbonensis) in Bale Highlands
}

\author{
Berhanu Tassew*, Aliyi Kedu, Teklu Wegi \\ Sinana Agricultural Research Center, Bale-Robe, Ethiopia \\ Email address: \\ berhanut42@gmail.com (B. Tassew) \\ ${ }^{*}$ Corresponding author \\ To cite this article: \\ Berhanu Tassew, Aliyi Kedu, Teklu Wegi. Effects of Different Seeding Rate and Row Spacing on Yield and Yield Components of Narbon \\ Vetch (Vicia narbonensis) in Bale Highlands. International Journal of Applied Agricultural Sciences. Vol. 6, No. 2, 2020 , pp. $21-25$. \\ doi: $10.11648 /$ j.jjaas.20200602.12
}

Received: April 3, 2020; Accepted: April 23, 2020; Published: May 19, 2020

\begin{abstract}
Narbon vetch (Vicia narbonensis) is among vetch species adapted to highlands of Bale. It is semi-erect to erect vetch with striking similar to faba bean. Seed rate and row spacing are among the most important factors affecting dry matter and seed yield of any crops. However, optimum seed rate and row spacing were not determined for narbon vetch under conditions of Bale high lands. Therefore, the experiment was conducted from 2014-2017 on research field of Sinana Agricultural Research Center, Sinana on-farm and Agarfa research subsite with the objective of determining optimum seed rate and row spacing for yield and yield components of narbon vetch under conditions of Bale highlands. Narbon vetch variety 'Abdeta' that was released from Sinana Agricultural Research Center in 2011 was used as a test crop for this experiment. The treatments consisted of three row spacing intervals $(20 \mathrm{~cm}, 30 \mathrm{~cm}$ and $40 \mathrm{~cm})$ and six seed rate levels $(30 \mathrm{Kg} / \mathrm{ha}, 45 \mathrm{Kg} / \mathrm{ha}, 60$ $\mathrm{kg} / \mathrm{ha}, 75 \mathrm{Kg} / \mathrm{ha}, 90 \mathrm{Kg} / \mathrm{ha}$ and $105 \mathrm{Kg} / \mathrm{ha}$ ) laid out in factorial combination of randomized complete block design (RCBD) replicated three times. The analysis of variance showed that seed rate and row spacing had a significant effect on yield and yield components of narbon vetch. The highest seed yield (43.22 qt/ha) was obtained from narbon vetch planted at a seed rate level of $60 \mathrm{~kg} / \mathrm{ha}$. Row spacing of $20 \mathrm{~cm}$ had also leaded to highest seed and dry matter yield. Based on the current study it was concluded that narbon vetch can be produced at a seed rate of $60 \mathrm{~kg} / \mathrm{ha}$ and $20 \mathrm{~cm}$ row spacing in high lands of Bale and similar agro-ecologies.
\end{abstract}

Keywords: Bale Highlands, Narbon Vetch, Row Spacing, Seed Rate, Yield, Yield Components

\section{Introduction}

Studies shows that livestock and crop production are interdependent in Bale highland where livestock holding was observed to have significant effect on crop cultivation [1]. However, regardless of their numeric and economic importance as well as the tremendous potential, the production and productivity of livestock is very low mainly due to poor nutrition, disease incidences and poor management.

Forage legumes enhance soil fertility, improve yield and nutritive value of crop residues, sustain feed production during the dry season, suppress weed and combat erosion [2]. In forage-animal production system, legumes are preferred owing to several advantages [3]. Cereals constitute forages relatively low in protein [4], and animals usually require some form of relatively costly protein concentrate supplementation [5].

Vetch is one of the most important annual forage legume already promoted for highlands of Bale. It is a very good pasture crop and is also grown as cover crop to protect the soil from erosion. Being legumes crop they not only improve soil fertility through biological nitrogen fixation but also have excellent nutritive value. These qualities have rendered them as potential forage crops [6]. It has also an important role in crop rotation before sowing of wheat and other cereals. Narbon vetch (Vicia narbonensis) is among vetch species adapted to highland of Bale. It is semi-erect to erect 
vetch with striking similar to faba bean. Studies have shown that, narbon vetch is an acceptable disease break for most cereal root diseases [7]. It has also higher protein contents compared to other vetch species [8].

There are many factors that affect productivity in agriculture. These factors are plant species and cultivars, agronomical techniques, soil and climate factors. Seeding rates is important agronomical technique affecting the yield of any crops. Earlier studies have also shown that seeding rate or planting density is an important factor affecting yield of grain legumes. Therefore, yield response of seed legumes to seed density was discussed by several authors, and different relative values between hay and seed yield with seed density were found [9-12]. Results that describe yield response to plant population alteration in different cultivation systems are highly variable. Other previous studies with several vetch species also indicated that the seeding rates influenced growth habit, morphological traits and yield [13, 14]. However, field experiments on the effects of seeding rates on the yield and yield components are very limited in narbon vetches.

Seeding rate can be influenced by the type and fertility of soil, climate, establishment methods (condition of seedbed and seeding methods), seed size, growth pattern of the crop and the like. Using higher or lower seed rate could have a negative impact on dry matter and seed yield of forage crops. On the other hand row spacing is another agronomical technique affecting yield and yield components of vetches [15]. However, optimum level of seeding rate and row spacing for narbon vetch was not determined yet for Bale highlands. Therefore, appropriate level of seeding rate and row spacing of narbon vetch need to be determined. Hence, this experiment was initiated with the objective to determine optimum seeding rate and row spacing for yield and yield components of narbon vetch under conditions of Bale highlands.

\section{Materials and Methods}

\subsection{Description of Experimental Sites}

The experiment was conducted on research field of Sinana Agricultural Research Center, Sinana on-farm and Agarfa research sub-site in the highlands of Bale, Southeastern Ethiopia under rain fed conditions during the main cropping season of 2014-2017. Sinana is located at a distance of about $463 \mathrm{Km}$ from Addis Ababa at about $07^{\circ} 07^{\prime} \mathrm{N}$ latitude and $40^{\circ} 10^{\prime} \mathrm{E}$ longitude and at an altitude of $2400 \mathrm{~m}$ above sea level. On the other hand, Agarfa is located at a distance of about $460 \mathrm{Km}$ from Addis Ababa in the southeastern direction situated in the highlands of Bale zone, Southeastern Oromia. It is situated $38^{\circ} 40^{\prime}$ to $46^{\circ} 3^{\prime}$ E longitude and $4^{\circ}$ to $8^{\circ} 11^{\prime} \mathrm{N}$ latitude at 2350 meters above sea level. The average annual maximum and minimum temperature are $21^{\circ} \mathrm{C}$ and $9^{\circ} \mathrm{C}$, respectively. The area is characterized by bimodal rainfall pattern with total annual precipitation ranging from 750 to $1000 \mathrm{~mm}$. Two distinct cropping seasons are known in the study area, locally known as Bona (Meher) which extends from August to December and Ganna (Belg) extending from March to July. The farming system is mainly mixed crop livestock production system and the major livestock raised in the study area are cattle, sheep, goats, equines and poultry. The common food crops grown around sinana area are cereals (mainly wheat), highland pulses, highland oil crops and horticultural crops, where as the major forage crop grown is fodder oat [16].

\subsection{Experimental Treatments and Design}

For this experiment, narbon vetch variety called 'Abdeta' was used as a test crop. It is a released variety from Sinana Agricultural Research Center in 2011. The treatments consisted of three row spacing intervals $(20 \mathrm{~cm}, 30 \mathrm{~cm}$ and $40 \mathrm{~cm}$ ) and six seed rate levels $(30 \mathrm{Kg} / \mathrm{ha}, 45 \mathrm{Kg} / \mathrm{ha}, 60$ $\mathrm{kg} / \mathrm{ha}, 75 \mathrm{Kg} / \mathrm{ha}, 90 \mathrm{Kg} / \mathrm{ha}$ and $105 \mathrm{Kg} / \mathrm{ha}$ ). The experiment was laid out in factorial combination of randomized complete block design (RCBD) replicated three times. Each plot consisted of $2 \mathrm{~m}$ long six rows. The adjacent blocks and plots were separated by $1.5 \mathrm{~m}$ and $1 \mathrm{~m}$ distances, respectively. Diammonium phosphate (DAP) fertilizer was applied at a recommended rate of $100 \mathrm{Kg} /$ ha to all plots.

\subsection{Data Collection}

The samples for plant height, leaf to stem ratio and dry matter yield determination were taken from two middle rows. The other two middle rows were used for seed yield and seed yield components data, while plants in the two outer rows were left aside to avoid border effects. Plant height (PH) was recorded by randomly measuring five plants from each plot and calculating average. Leaf to stem ratio (LSR) was determined by taking $200 \mathrm{~g}$ sample, partitioning the sample to leaf and stem, drying in an oven at $65^{\circ} \mathrm{C}$ for 72 hours and calculating the ratio. Dry matter yield (DMY) was determined by harvesting the two middle rows and measuring, taking $500 \mathrm{~g}$ sample and drying in an oven at $65^{\circ} \mathrm{C}$ for 72 hours. Average number of pods per plant (ANPP) were determined by randomly taking five plants and counting number of effective pods per each plant and calculating average. Average number of seed per pod (ANSP) was recorded by counting the number of seed in each counted pod for ANPP and calculating average. Seed yield (SY) data was taken from the two middle rows and converting to hectare. Thousand kernel weight (TKW) was recorded by counting 1000 seed by seed counter machine and weighing by sensitive balance.

\subsection{Data Analysis}

All collected data were subjected to analysis of variance (ANOVA) using the General Linear Model (GLM) procedure of SAS [17] version 9.1. When significant, least significant difference (LSD) test was employed to locate differences between the treatment means. Pearson's correlation analysis was employed to determine the association among yield and yield components. 


\section{Results and Discussion}

\subsection{Effects of Seed Rate and Row Spacing on Yield and Vield Components of Narbon Vetch}

The analysis of variance revealed that the interaction effect of seed rate and row spacing on yield and yield components of narbon vetch is not significantly different $(\mathrm{P}>0.05)$. This shows that changing the level of seed rate produces the same effect at different levels of row spacing and vice versa. However, the main effects of seed rate and row spacing showed significant differences $(\mathrm{P} \leq 0.05)$ on some considered parameters (Table 1). The analysis of variance for plant height, leaf to stem ratio, dry matter yield and average number of pod per plant revealed significant differences $(\mathrm{P} \leq 0.05)$ with varying seed rate levels. However, the main effect of seed rate did not significantly influence $(\mathrm{P}>0.05)$ average number of seed per pod, seed yield and thousand kernel weight of narbon vetch. The result shows that plant height increases with increasing seed rate level. Plant height at 90 and $105 \mathrm{~kg} / \mathrm{ha}$ seed rate levels is significantly higher $(\mathrm{P} \leq 0.05)$ than plant height at 30 and $45 \mathrm{~kg} / \mathrm{ha}$ seed rate levels. Different authors also reported height of plants increases with increasing seed rate $[18,19]$. This is because high plant density remains with minimum space for horizontal expansion of the plant and increase the competition for light interception between plants that drives upward growth. This result, however, did not coincide with the study [20-22] who reported that increase in the seeding rate resulted in a slight decline in the heights of the plants. This could be because of variable environmental conditions and plant species in all these studies.

A seeding rate of 30 and $45 \mathrm{~kg} /$ ha resulted in significantly higher $(\mathrm{P} \leq 0.05)$ than a seeding rate of 90 and $105 \mathrm{~kg} / \mathrm{ha}$ which shows plants become more leafy at lower seed densities. This might be because of lower competition for nutrients and light at lower seed rates. Dry matter yield showed an increasing trend with increasing seed densities. The dry matter yield obtained at seed rate level of $105 \mathrm{~kg} / \mathrm{ha}$ is significantly higher $(\mathrm{P} \leq 0.05)$ than dry matter obtained at a seed rates of 30 and $45 \mathrm{~kg} / \mathrm{ha}$. This is because of higher plant densities as seed rate increases which resulted to higher dry matter yield. Average number of pods per plant showed a decreasing trend with increasing level of seed rates (Table 1). The average number of pod per plant at a seed rate level of $30 \mathrm{~kg} / \mathrm{ha}$ was significantly higher $(\mathrm{P} \leq 0.05)$ than the other seed rate levels except seed rate level of $45 \mathrm{~kg} / \mathrm{ha}$. The decrease in number of pods per plant with increase in plant density could be due to increased intra specific competition, which eventually caused reduction in number of pods per plant. In agreement with this study, [23] who worked on haricot bean reported appreciable increase in number of pod per plant with decreasing plant population densities.

Table 1. Main effects of seed rate and row spacing on yield and yield components of narbon vetch

\begin{tabular}{|c|c|c|c|c|c|c|c|}
\hline \multirow{2}{*}{ Treatments } & \multicolumn{7}{|c|}{ Parameters } \\
\hline & PH (cm) & LSR & DMY (t/ha) & ANPP & ANSP & SY (qt/ha) & TKW (g) \\
\hline \multicolumn{8}{|c|}{ Seed rate $(\mathrm{kg} / \mathrm{ha})$} \\
\hline 30 & $93.56^{\mathrm{c}}$ & $0.6^{\mathrm{a}}$ & $5.87^{\mathrm{c}}$ & $36.94^{\mathrm{a}}$ & 5.12 & 38.13 & 181.0 \\
\hline 45 & $99.5 b^{c}$ & $0.57^{\mathrm{ab}}$ & $6.16^{\mathrm{bc}}$ & $32.44^{\mathrm{ab}}$ & 4.61 & 41.22 & 181.78 \\
\hline 60 & $108.28^{\mathrm{abc}}$ & $0.52^{\mathrm{abc}}$ & $7.11^{\mathrm{abc}}$ & $28.22^{b c}$ & 4.52 & 43.22 & 187.11 \\
\hline 75 & $107.89^{\mathrm{abc}}$ & $0.54^{\mathrm{abc}}$ & $6.96^{\mathrm{abc}}$ & $22.5^{\mathrm{c}}$ & 4.75 & 40.64 & 174.67 \\
\hline 105 & $119.56^{\mathrm{a}}$ & $0.45^{\mathrm{c}}$ & $7.71^{\mathrm{a}}$ & $23.28^{\mathrm{c}}$ & 4.67 & 38.59 & 176.11 \\
\hline $\operatorname{LSD}(\mathrm{P} \leqq 0.05)$ & 16.77 & 0.1 & 1.36 & 6.03 & ns & ns & ns \\
\hline \multicolumn{8}{|c|}{ Row spacing (cm) } \\
\hline 20 & 107.72 & 0.51 & $8.0^{\mathrm{a}}$ & 29.47 & $4.54^{\mathrm{ab}}$ & $44.6^{\mathrm{a}}$ & 178.39 \\
\hline 30 & 107.19 & 0.54 & $6.71^{b}$ & 28.83 & $4.5^{\mathrm{b}}$ & $39.19^{\mathrm{ab}}$ & 176.39 \\
\hline 40 & 105.22 & 0.55 & $5.93^{\mathrm{b}}$ & 26.5 & $5.09^{\mathrm{a}}$ & $37.62^{b}$ & 185.39 \\
\hline Mean & 106.71 & 0.53 & 6.88 & 28.27 & 4.71 & 40.47 & 180.06 \\
\hline CV (\%) & 23.66 & 27.29 & 29.7 & 32.10 & 26.28 & 32.1 & 13.75 \\
\hline
\end{tabular}

a, b, c means with different superscripts in a column are significantly different at 0.05 level of significance; ANPP $=$ Average number of pods per plant; $\mathrm{ANSP}=$ Average number of seeds per pod; CV $(\%)=$ Coefficient of variation $(\%)$; DMY=Dry matter yield; LSR=Leaf to stem ratio; LSD=Least significant difference; $n s=$ Not significant; $\mathrm{PH}=$ Plant height; $\mathrm{SY}=$ Seed yield; $\mathrm{TKW}=$ Thousand kernel weight.

The analysis of variance for dry matter yield, average number of seed per pod and seed yield revealed significant differences $(\mathrm{P} \leq 0.05)$ with varying row spacing intervals. However, the main effect of row spacing did not significantly influence $(\mathrm{P}>0.05)$ plant height, leaf to stem ratio, average number of pod per plant and thousand kernel weight of narbon vetch. The result showed that the dry matter yield tends to decrease with increasing row spacing. The significantly highest $(\mathrm{P} \leq 0.05)$ dry matter yield was recorded for $20 \mathrm{~cm}$ row spacing intervals. The $20 \mathrm{~cm}$ row spacing resulted to $34.91 \%$ dry matter yield advantage over $40 \mathrm{~cm}$ row spacing. This is the result of higher plant densities at lower row spacing interval. It also shows that since narbon vetch does not spread as that of other vetch species it did not require wide row spacing interval.

Average number of seed per pod showed an increasing pattern with increasing row spacing. Plants compete for limited resources being essential for their life, i.e. light, 
water, and nutrients. Yet, whole plant growth and competitive ability depends not only on the photosynthetic rate of individual leaves, but also on the geometry and dynamics of a plant's canopy, and the pattern of energy allocation among all organs [24]. As the number of plants within a row increased, intra row plant competition got increased while light interception reduced and resulted in decreased number of seeds per pod. In agreement with the present result, the number of seeds per pod reported increased with decreased plant density of faba bean [25-27]. Moreover, in chickpea higher number of seeds per pod was reported in association with wider inter and intra-row spacing [28]. Seed yield at $20 \mathrm{~cm}$ row spacing was significantly higher $(\mathrm{P} \leq 0.05)$ than seed yield at $40 \mathrm{~cm}$ row spacing. The $20 \mathrm{~cm}$ row spacing resulted to $12.11 \%$ seed yield advantage over $40 \mathrm{~cm}$ row spacing. This also shows that for narbon vetch row spacing of greater than $20 \mathrm{~cm}$ is not desired, as it is wastage of land.

\subsection{Pearson's Correlation Analysis of Yield and Yield Component Parameters of Narbon Vetch Under Different Seed Rate Levels and Row Spacing Intervals}

Correlations between yield and yield components of narbon vetch are given in table 2. DM yield was positively and significantly correlated with plant height $(\mathrm{r}=0.69 * * *)$ and seed yield $\left(\mathrm{r}=0.44^{* *}\right)$. This indicates that plant height is major biomass yield component affecting dry matter yield. However, it was negatively correlated with ANPP $(\mathrm{r}=-0.08)$, ANSP $(r=-0.04)$, TKW $(r=-0.27)$ and LSR $(r=-0.53)$. Seed yield was positively and significantly correlated with $\mathrm{PH}$ $(\mathrm{r}=0.34 * * *)$ and dry matter yield $(\mathrm{r}=0.44 * * *)$. [29] also reported positive significant association between seed yield and plant height. This also indicates that seed yield depends on the achievement of better vegetative development and larger stem reserve mobilization [30].

Table 2. Correlation coefficient of yield and yield component parameters of narbon vetch under different seed rate levels and row spacing intervals.

\begin{tabular}{|c|c|c|c|c|c|c|c|}
\hline Parameters & PH & LSR & DMY & ANPP & ANSP & SY & TKW \\
\hline $\mathrm{PH}$ & 1.00 & & & & & & \\
\hline LSR & $-0.72 * * *$ & 1.00 & & & & & \\
\hline DMY & $0.69^{* * *}$ & $-0.53 * * *$ & 1.00 & & & & \\
\hline ANPP & $-0.26 * *$ & $0.26^{* *}$ & $-0.08 \mathrm{~ns}$ & 1.00 & & & \\
\hline ANSP & $0.05 \mathrm{~ns}$ & $0.07 \mathrm{~ns}$ & $-0.04 n s$ & $-0.35 * * *$ & 1.00 & & \\
\hline SY & $0.34 * * *$ & $-0.31 * *$ & $0.44 * * *$ & $0.09 \mathrm{~ns}$ & $-0.05 n s$ & 1.00 & \\
\hline TKW & $-0.26 * *$ & $0.16 \mathrm{~ns}$ & $-0.27 * *$ & $0.04 \mathrm{~ns}$ & $0.01 \mathrm{~ns}$ & $0.01 \mathrm{~ns}$ & 1.00 \\
\hline
\end{tabular}

$*=(\mathrm{P}<0.05) ; * *=(\mathrm{P}<0.01) ; * * *=(\mathrm{P}<0.001) ;$ ANPP $=$ Average number of pods per plant; ANSP=Average number of seeds per pod; DMY $=$ Dry matter yield; $\mathrm{LSR}=$ Leaf to stem ratio; $\mathrm{ns}=$ Not significant; $\mathrm{PH}=$ Plant height; $\mathrm{SY}=$ Seed yield; TKW=Thousand kernel weight.

\section{Conclusions}

The study concluded that seed rate and row spacing had a significant effect on yield and yield components of narbon vetch. The highest seed yield (43.22 qt/ha) was obtained from narbon vetch planted at a seed rate level of $60 \mathrm{~kg} / \mathrm{ha}$. Row spacing of $20 \mathrm{~cm}$ has also leaded to highest seed and dry matter yield. Based on the current study it can be concluded that narbon vetch can be produced at a seed rate of $60 \mathrm{~kg} / \mathrm{ha}$ and $20 \mathrm{~cm}$ row spacing in high lands of Bale and similar agro-ecologies.

\section{Acknowledgements}

The author would like to acknowledge the Oromia Agricultural Research Institute and Sinana Agricultural Research Centre for granting and facilitating this research work.

\section{References}

[1] Solomon Bogale, Solomon Melaku and AlemuYami. 2009. The Interdependence of Crop Livestock Production Sectors: The Case of Sinana Dinsho District in Bale Highlands of Ethiopia. Tropical and Subtropical Agro ecosystems, 42 (2): 65-71.

[2] Humphrey, L. R. 1994. Tropical forages: their role in sustainable agriculture. The University of Queens land.
Australia.

[3] Haynes, R. J. 1980. Competitive aspects of the grass-legume association. Adv. Agronomy. 33: 227-261.

[4] Robinson, R. C. 1969. Annual legume: cereal mixtures for forage and seed. Agro. J. 61: 759-761.

[5] Anil, L., Park, J., Phipps, R. H, Miller, F. A. 1998. Temperate intercropping of cereals for forage: a review of the potential for growth and utilization with particular reference to the UK. Grass Forage Sciences, 53: 301-317.

[6] Hughes, H. D., M. E. Heath and D. S. Metcalfe. 1969. Forages The Lowa State University Press, Ames, Iowa, USA. p. 707.

[7] Hailu Keno and Lulseged Gebrehiwot. 1983. prospects of vetches (Vicia spp.) as forage legumes for the highlands of Ethiopia. Ethiopian Journal of Agricultural Science 5 (2): 131138.

[8] Dawit Abate, Aliye Kadu and Sisay Belete. 2011. Registration of Abdeta, Gebisa and Lalisa Vetch Varieties for Bale Highlands, Ethiopia. East African Journal of Sciences, 5 (2): 135-137.

[9] McEwen J., DP. Yeoman R. Moffitt. 1988. Effect of seed rates, sowing dates and methods of sowing on autumn sown field beans (Vicia faba L.). J. Agric. Sci. Cambridge 110, p. 345-352.

[10] Martiniello, P. and A. Ciola. 1995. Dry matter and seed yield of mediterranean annual legume species. Agron. J., 87: 985993. 
[11] Noffsinger LS., E. Santen. 1995. Yield and yield components of spring- sown white lupin in the south easternUSA. Agron. J. 87: p. 493-497 production in Crimea. Herb. Abs., 43: 63.

[12] Tawaha AM., Turk MA. 2001. Effect of date and rate of sowing on yield and yield components of narbon vetch under semi-arid condition. Acta Agron. Hung. 49 (1): p. 103-105.

[13] Aydogdu, L. and E. Acikgoz. 1995. Effect of seeding rate on seed and hay yield in common vetch (Vicia sativa L.). J. Agron. and Crop Sci., 174: 181-187.

[14] Seymour, M., K. H. M. Siddique, N. Brandon, L. Martin and E. Jackson. 2002. Response of vetch (Vicia spp.) to plant density in south western Australia. Australian J. Exp. Agric., 42: 1043-1051.

[15] Tamer Yavuz, Mustafa Surmen and Necda Cankaya. 2011. Effect of row spacing and seeding rate on yield and yield components of common vetch (vicia sativa. L). Journal of Food, Agriculture and Environment. Helsinki, Finland. Volume 9 (1): 369-371.

[16] SARC (Sinana Agricultural Research Center). 2014. Information bulletin on major achievements. Bale, Ethiopia.

[17] SAS (Statistical Analysis System) Institute Inc. 2004. SAS Online Doc® 9.1.3. Cary, NC: SAS Institute Inc.

[18] Alemayehu A, Wassu M, Tamado T. 2015. Effect of Seed Sources and Rates on Productivity of Bread Wheat (Triticum aestivum 1.) Varieties at Kersa, Eastern Ethiopia, MSc thesis.

[19] Tewodros Ayalew, bereket abebe and Tarekegn Yoseph. 2017. Response of wheat (Tritium aestivum L.) to variable seed rates: the case of hawassa area, southern Ethiopia. African Journal of Agricultural Research. Vol. 12 (14), pp. 1177-1181, 6 April, 2017. DOI: 10.5897/AJAR2017.12196.

[20] Abbas G, Ali MA, Azam M, Hussain I. 2009. Impact of Planting Methods on Wheat Grain Yield and Yield Contributing parameters. J. Anim. Plant Sci. 19 (1): 30-33.

[21] Baloch MS, Shah ITH, Nadim MA, Khan MI, Khakwani AA. 2010. Effect of Seeding Density, and Planting Time on Growth and Yield Attributes Wheat. J. Anim. Plant Sci. 20 (4): 239-240.
[22] Bekalu abeba and Arega Abebe. 2016. Effect of seed rate on yield and yield componenets of tef ((Eragrostic tef) trotter) at shebedino, southern Ethiopia. Journal of Natural Sciences Research. ISSN 2224-3186 (Paper) ISSN 2225-0921 (Online). Vol. 6, No. 21.

[23] Mulatu Gabisa, Ejigu Ejara and Zinash Misgana. 2017. Effect of phosphorus application and plant density on yield and yield components of haricot bean (Phaseolus vulgaris l.) at yabello southern Ehiopia. International Journal of Scientific Engineering and Applied Science (IJSEAS). Volume-3, Issue3, March 2017 ISSN: 2395-3470. www.ijseas.com.

[24] Ball, R. A., L. C. Purcell and E. D. Vories. 2000. Short-season soybean yield compensation in response to population and water regime. Crop Science, 40: 1070-1078.

[25] Abo El-Zahab, A. A., A. A. Al-Babawy and I. S. Nidway. 1981. Density studies on faba beans (Viciafaba L.) II: Growth parameters. Agronomy and Crop Science Journal, 150: 303312 .

[26] Ayaz, S., D. L. McNeil, B. A. McKenzie and G. D. Hill. 2001. Density and sowing depth effects on yield components of grain legumes. Proceedings of Agronomic Society. New Zealand, 29: 9-15.

[27] Abdel, L. Y. I. 2008. Effect of seed size and plant spacing on yield and yield components of faba bean (Viciafaba L.). Research Journal of Agriculture Biological Science, 4 (2): 146-148.

[28] Melak Agajie. 2018. Effect of spacing on yield components and yield of chickpea (Cicer arietinumL.) at Assosa, Western Ethiopia. Agriculture, Forestry and Fisheries. Vol. 7, No. 2, 2018, pp. 39-51. doi: 10.11648/j.aff.20180702.11.

[29] Ashinie Bogale and Kindie Tesfaye. 2016. Relationship between grain yield components of the Ethiopian durum wheat genotypes at various growth stages. Tropical and subtropical agroecosystems, vol. 19, núm. 1, 2016, pp. 8191Universidad Autónoma de Yucatán, Mérida, Yucatán, México.

[30] Khan, A. J., F. Azam. Ali A. 2010. Relationship of morphological traits and grain yield in recombinant inbred wheat lines grown under drought conditions. Pakistan Journal of Botany, 42 (1): 259-267. 